\title{
Uji Efektivitas Pupuk Organonitrofos dan Kombinasinya dengan Pupuk Kimia Terhadap Pertumbuhan, Serapan Hara dan Produksi Tanaman Jagung Manis (Zea mays saccharata) di Musim Tanam Ketiga pada Tanah Ultisol Gedung Meneng
}

\section{Fertilizer Organonitrofos Effectiveness Test and The combination with Chemical Fertilizer on Growth, Nutrient Uptake and Sweet Corn Crop Production (Zea mays saccharata) on Third Planting Season on Ultisol Land Gedung Meneng}

\author{
Eka Purnama Sari ${ }^{1}$, Jamalam Lumbanraja ${ }^{2}$, Henrie Buchari ${ }^{2}$, dan Ainin \\ Niswati $^{2}$ \\ ${ }^{1}$ Mahasiswa dan ${ }^{2}$ Dosen Jurusan Agroteknologi Fakultas Pertanian Universitas Lampung \\ Jln. Prof. Soemantri Brodjonegoro, No. 1 Bandar Lampung 35145 \\ Korespondensi: eka.purnamasari17@ymail.com
}

\begin{abstract}
Organonitrofos fertilizer is organic fertilizer derived from cow manure enriched with rock phosphate and microbial activity involves fastening $N$ and phosphate newly developed solvent. This study aimed to determine dose combination Organonitrofos fertilizers and inorganic fertilizers are most effective against the growth, nutrient uptake, and yield of sweet corn. This research was conducted in November 2012 until March 2013 in the Integrated Field Laboratory, University of Lampung using Random Design (RBD) consisting of 6 treatments with 3 groups. Treatment A (control), B (300 $\mathrm{kg}$ Urea ha $\mathrm{h}^{-1}, 200 \mathrm{~kg}$ of SP-36 ha-1, $100 \mathrm{~kg}$ of KCl ha- $), C$ (225 kg Urea ha ${ }^{-1}, 150 \mathrm{~kg}$ $S P-36 \mathrm{ha}^{-1}, 75 \mathrm{~kg} \mathrm{KCl} \mathrm{ha} a^{-1}, 1000 \mathrm{~kg}$ Organonitrofos ha $\left.{ }^{-1}\right), D\left(150 \mathrm{~kg}\right.$ Urea ha ${ }^{-1}, 100 \mathrm{~kg}$ of SP-36 ha- , $50 \mathrm{~kg}$ of $\mathrm{KCl} \mathrm{ha}^{-1}, 1,500 \mathrm{~kg}$ Organonitrofos ha ${ }^{-1}$ ), E (Urea $75 \mathrm{~kg} \mathrm{ha}^{-1}, S P$ -

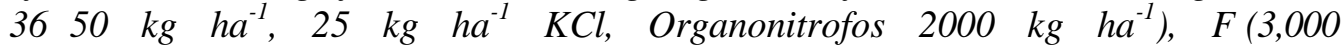
Organonitrofos $\left.\mathrm{kg} \mathrm{ha}^{-1}\right)$. The results showed that treatment at a dose of $150 \mathrm{~kg}$ of urea

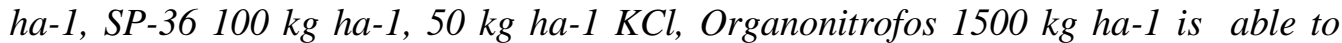
increase the growth, production and sweet corn crop nutrient uptake. This treatment was also the most effective treatment of the total biomass of sweet corn plants based on calculations Relative Agronomic Effectivenes (RAE) that is equal to 108.573\%. Economical test results showed that treatment at a dose of $300 \mathrm{~kg}$ of urea ha-1, SP-36 $200 \mathrm{~kg} \mathrm{ha}-1,100 \mathrm{~kg} \mathrm{ha}-1 \mathrm{KCl}$ most economical compared to other treatments.
\end{abstract}

Keywords: sweet corn, the combination of fertilizer, organonitrofos, nutrient uptake

Diterima: 24-12-2014 : disetujui 23-10-2015

\section{PENDAHULUAN}

Jagung manis (Zea mays saccharata) atau yang lebih dikenal dengan nama sweet corn mulai dikembangkan di Indonesia pada awal tahun 1980, diusahakan secara komersial dalam skala kecil 

(Koswara, 1986). Permintaan akan jagung manis semakin meningkat. Hal ini disebabkan jagung manis memiliki rasa yang lebih manis dibandingkan dengan jagung biasa. Selain itu, umur produksi lebih pendek (genjah) sehingga sangat menguntungkan (Rukmana, 1997). Hal ini dapat dilihat dari besarnya jumlah impor jagung manis pada tahun 2012 yang mencapai 2.674 ton (Direktorat Jenderal Horikultura, 2012). Akan tetapi peningkatan permintaan yang tinggi tersebut belum dapat dipenuhi karena masih rendahnya produksi jagung manis di Indonesia saat ini yang rata-rata hanya sebesar 8,31 $\mathrm{t} \mathrm{ha}^{-1}$ sehingga belum mampu memenuhi kebutuhan dalam negeri. Produktivitas jagung manis yang rendah di Indonesia disebabkan karena pembudidayaan dilakukan pada lahan berkesuburan tanah rendah. Sebagian besar tanah di Lampung adalah Tanah Ultisol yaitu dengan luasan sekitar 1,5 juta hektar (Badan Koordinasi Penanaman Modal, 2011).

Ultisol merupakan salah satu jenis tanah mineral masam yang merupakan potensi besar untuk perluasan dan peningkatan produksi pertanian di Indonesia. Kendala utama yang dijumpai didalam kaitannya dengan pengembangan Ultisol untuk lahan pertanian terutama karena termasuk tanah yang mempunyai ketersediaan hara yang rendah (Prahastuti, 2005). Pemupukan adalah salah satu cara untuk mengatasi kendala pada tanah Ultisol. Sutejo, (1995) dan Roesmarkam dan Yuwono (2002) menyatakan bahwa pemupukan dimaksudkan untuk mengganti kehilangan unsur hara pada media atau tanah dan merupakan salah satu usaha yang penting untuk meningkatkan pertumbuhan dan produksi

tanaman. Pupuk yang sudah dikenal ada 2 jenis yaitu pupuk organik dan pupuk kimia. Pupuk kimia mampu menyediakan unsur hara yang dibutuhkan oleh tanaman. Akan tetapi, akhir-akhir ini petani skala kecil sangat sulit untuk mendapatkan pupuk kimia tersebut dikarenakan kondisinya yang langka

dan harganya yang melambung tinggi (Agromedia, 2010). Hal ini perlu diatasi dengan cara mengurangi penggunaan pupuk kimia dengan menggunakan pupuk organik yang harganya lebih murah dan ramah lingkungan (Syukur, 2005). Pupuk organik yang dicobakan dalam penelitian ini yaitu pupuk alternatif Organonitrofos. Pupuk Organonitrofos dibuat dari 70-80 \% kotoran sapi dan 20-

$30 \%$ batuan fosfat, dengan penambahan mikroba penambat $\mathrm{N}$ dan pelarut $\mathrm{P}$ (Nugroho et al.,

2012). Pupuk tersebut diharapkan mampu mengurangi kebutuhan pupuk kimia sehingga mampu $m$

Untuk itu perlu dilakukan pengujian dengan beberapa kombinasi pada tanaman jagung manis yang nantinya diharapkan mampu mengurangi penggunaan pupuk kimia. Penelitian yang sama telah dilakukan pada tanaman jagung (Septima, 2012) dimusim tanam pertama dan (Deviana, 2013) dimusim tanam kedua. Penelitian ini bertujuan untuk menetapkan dosis kombinasi pupuk Organonitrofos dan pupuk anorganik yang paling efektif terhadap pertumbuhan, serapan hara, dan produksi tanaman jagung manis.

\section{METODE}

Penelitian dilakukan di Laboratorium Lapang Terpadu Universitas Lampung pada $5^{\circ} 22^{\prime} 10^{\prime \prime} L S$ dan $105^{\circ} 14^{\prime} 38^{\prime \prime}$ BT dengan ketinggian 146m dpl. Analisis dilakukan di Laboratorium Ilmu Tanah Universitas Lampung. Penelitian pada musim tanam ketiga dilakukan pada lokasi dan petak percobaan yang sama dengan musim tanam pertama dan musim tanam kedua. Penelitian ini dilakukan pada bulan Mei sampai Desember 2013.

Penelitian dilakukan dengan menggunakan Rancangan Acak Kelompok (RAK) yang terdiri dari 6 perlakuan dengan 3 kelompok. Perlakuan berdasarkan dosis pupuk yang diberikan yaitu : $\mathrm{A}=$

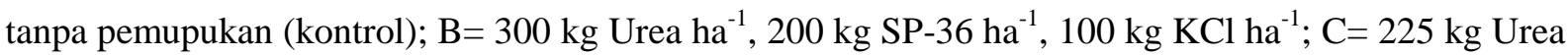
$\mathrm{ha}^{-1}, 150 \mathrm{~kg} \mathrm{SP}-36 \mathrm{ha}^{-1}, 75 \mathrm{~kg} \mathrm{KCl} \mathrm{ha}^{-1}, 1000 \mathrm{~kg}$ Organonitrofos ha ${ }^{-1} ; \mathrm{D}=150 \mathrm{~kg}$ Urea ha $^{-1}, 100 \mathrm{~kg} \mathrm{SP}-$ 
$36 \mathrm{ha}^{-1}, 50 \mathrm{~kg} \mathrm{KCl} \mathrm{ha}^{-1}, 1.500 \mathrm{~kg}$ Organonitrofos ha ${ }^{-1} ; \mathrm{E}=75 \mathrm{~kg}$ Urea ha $^{-1}, 50 \mathrm{~kg} \mathrm{SP}-36 \mathrm{ha}^{-1}, 25 \mathrm{~kg} \mathrm{KCl}$ $\mathrm{ha}^{-1}, 2.000 \mathrm{~kg}$ Organonitrofos ha ${ }^{-1} ; \mathrm{F}=3.000 \mathrm{~kg}$ Organonitrofos ha ${ }^{-1}$.

Lahan yang digunakan merupakan lahan bekas pertanaman jagung pada musim tanam pertama dan musim tanam kedua yang telah diberi perlakuan. Pengolahan lahan diawali dengan pembersihan lahan dari sisa-sisa tanaman sebelumnya. Kemudian tanah digemburkan hingga kedalaman 15-20 cm dengan menggunakan cangkul. Setelah tanah diolah petak percobaan dibuat masing-masing dengan ukuran $3 \times 3 \mathrm{~m}$ dengan jarak antar petak $50 \mathrm{~cm}$. Penanaman jagung manis dilakukan dengan jarak tanam $75 \times 25 \mathrm{~cm}$. Kemudian dimasukkan 2 benih jagung manis di setiap lubang tanam. Aplikasi pupuk Organonitrofos dilakukan saat 1 minggu sebelum tanam. Pengaplikasian pupuk urea dilakukan sebanyak dua kali. Aplikasi pupuk urea pertama $1 / 2$ dosis dilakukan pada 2 MST (minggu setelah tanam) bersamaan dengan pupuk SP-36 dan $\mathrm{KCl}$. Aplikasi pupuk urea kedua (sisa $1 / 2$ dosis) dilakukan pada saat muncul malai. Pemeliharaan meliputi penyiraman, penyiangan, penjarangan, dan pembumbunan. Sampel tanah diambil secara komposit dengan lima titik pengambilan sampel untuk masing-masing perlakuan. Sampel tanah diambil dua kali, yaitu sebelum tanam dan setelah pemanenan. Pengambilan sampel tanaman dilakukan setelah jagung dipanen. Sampel tanaman yang diambil yaitu seluruh bagian tanaman kecuali akar. Kemudian dikeringkan dalam oven pada suhu $70^{\circ}$ $\mathrm{C}$ selama tiga hari. Parameter pengamatan yang diamati pada penelitian ini meliputi tinggi tanaman, jumlah daun, bobot berangkasan, bobot tongkol, analisis tanah (N-total, P-tersedia, K-dd, C-organik, dan $\mathrm{pH}$ tanah), analisis tanaman (N, P, dan K), uji efektivitas pupuk, uji korelasi, dan uji ekonomis.

\section{HASIL DAN PEMBAHASAN}

\section{Sifat Kimia Tanah Awal dan Akhir}

Berdasarkan hasil analisis tanah awal dan analisis tanah akhir (Tabel 1.) menunjukan bahwa pemberian pupuk Organonitrofos dan pupuk kimia dengan berbagai kombinasinya hanya dapat meningkatkan K-dd. Sedangkan $\mathrm{pH}$ tanah, C-organik, N-total, P-tersedia mengalami penurunan.

Tabel 1. Hasil analisi kimia tanah awal (akhir musim tanam kedua) dan hasil analisis tanah akhir setelah dilakukan aplikasi pupuk Organonitrofos dengan pupuk kimia dimusim tanamketiga.

\begin{tabular}{|c|c|c|c|c|c|c|c|}
\hline \multirow{2}{*}{ Jenis Analisis } & & \multicolumn{6}{|c|}{ Perlakuan } \\
\hline & & A & B & $\mathrm{C}$ & D & $\mathrm{E}$ & $\mathrm{F}$ \\
\hline \multirow{2}{*}{$\begin{array}{l}\text { N-total } \\
(\%)\end{array}$} & Awal & $0,11(\mathrm{R})$ & $0,25(\mathrm{~S})$ & $0,31(\mathrm{~S})$ & $0,23(\mathrm{~S})$ & $0,25(\mathrm{R})$ & $0,21(\mathrm{R})$ \\
\hline & Akhir & $0,16(\mathrm{R})$ & $0,24(\mathrm{~S})$ & $0,21(\mathrm{~S})$ & $0,32(\mathrm{~S})$ & $0,19(\mathrm{R})$ & $0,18(\mathrm{R})$ \\
\hline \multirow{2}{*}{$\begin{array}{l}\text { P-tersedia } \\
(\mathrm{ppm})\end{array}$} & Awal & 4,7 (SR) & 9,6 (SR) & 4,9 (SR) & $10,2(\mathrm{R})$ & $12,6(\mathrm{R})$ & 7,0 (SR) \\
\hline & Akhir & 1,24 (SR) & $5,49(\mathrm{R})$ & $5,39(\mathrm{R})$ & $5,83(\mathrm{R})$ & $4,63(\mathrm{R})$ & 1,61 (SR) \\
\hline \multirow{2}{*}{$\begin{array}{l}\text { K-dd } \\
\left(\text { me } 100 \mathrm{~g}^{-1}\right)\end{array}$} & Awal & $0,48(\mathrm{~S})$ & $0,85(\mathrm{~T})$ & $0,75(\mathrm{~T})$ & $0,73(\mathrm{~T})$ & $0,78(\mathrm{~T})$ & $0,89(\mathrm{~T})$ \\
\hline & Akhir & $0,82(\mathrm{~T})$ & $1,00(\mathrm{~T})$ & $0,94(\mathrm{~T})$ & $1,02(\mathrm{ST})$ & $0,86(\mathrm{~T})$ & $0,83(\mathrm{~T})$ \\
\hline \multirow{2}{*}{$\begin{array}{l}\text { C-organik } \\
(\%)\end{array}$} & Awal & $1,22(\mathrm{~S})$ & $2,04(\mathrm{~S})$ & $2,09(\mathrm{~S})$ & $2,19(\mathrm{~S})$ & $2,29(\mathrm{~S})$ & $2,25(\mathrm{~S})$ \\
\hline & Akhir & $1,38(\mathrm{~S})$ & $2,04(\mathrm{~S})$ & $1,92(\mathrm{~S})$ & $2,19(\mathrm{~S})$ & $1,94(\mathrm{~S})$ & $1,89(\mathrm{~S})$ \\
\hline \multirow{2}{*}{$\begin{array}{l}\mathrm{pH} \\
(\mathrm{H} 2 \mathrm{O})\end{array}$} & Awal & $\begin{array}{c}6,02 \\
(\mathrm{AM})\end{array}$ & $\begin{array}{l}6,08 \\
\text { (AM) }\end{array}$ & $6,18(\mathrm{AM})$ & $6,21(\mathrm{AM})$ & $6,32(\mathrm{AM})$ & $6,24(\mathrm{AM})$ \\
\hline & Akhir & 5,9 (AM) & (AM) & $5,93(\mathrm{AM})$ & $5,73(\mathrm{AM})$ & $5,94(\mathrm{AM})$ & $5,86(\mathrm{AM})$ \\
\hline
\end{tabular}

Keterangan: A= tanpa pemupukan (kontrol); B= $300 \mathrm{~kg} \mathrm{Urea} \mathrm{ha}^{-1}, 200 \mathrm{~kg} \mathrm{SP}-36 \mathrm{ha}^{-1}, 100 \mathrm{~kg} \mathrm{KCl} \mathrm{ha}^{-1} ; \mathrm{C}=225 \mathrm{~kg} \mathrm{Urea} \mathrm{ha}^{-1}$,

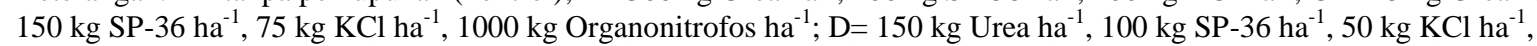
$1.500 \mathrm{~kg}$ Organonitrofos ha $^{-1} ; \mathrm{E}=75 \mathrm{~kg} \mathrm{Urea} \mathrm{ha}^{-1}, 50 \mathrm{~kg} \mathrm{SP}^{-36} \mathrm{ha}^{-1}, 25 \mathrm{~kg} \mathrm{KCl} \mathrm{ha}^{-1}, 2.000 \mathrm{~kg}$ Organonitrofos ha $^{-1} ; \mathrm{F}=3.000$ $\mathrm{kg}$ Organonitrofos $\mathrm{ha}^{-1} ; \mathrm{T}=$ tinggi; $\mathrm{S}=$ sedang; $\mathrm{R}=$ rendah; $\mathrm{SR}=$ sangat rendah; $\mathrm{AM}=$ agak masam 
Eka Purnama Sari dkk: Uji Efektivitas Pupuk Organonitrofos dan Kombinasinya dengan Pupuk Kimia...

Pengaruh Aplikasi Pupuk Organonitrofos dan Kombinasinya dengan Pupuk Kimia terhadap Pertumbuhan Vegetatif Tanaman Jagung Manis

Hasil penelitian menunjukkan bahwa tinggi tanaman dan jumlah daun tanaman jagung manis tidak berbeda nyata disemua perlakuan (Gambar 1 dan 2). Berdasarkan hasil analisis tanah awal sebelum dilakukan penanaman musim tanam kedua kandungan C-organik berkisar antara 1,22 2,29\%, N-total berkisar antara 0,11 - 0,31\%, P-tersedia berkisar antara 4,7 - 12,6 ppm dan K-dd berkisar antara $0,48-0,89 \mathrm{cmol} \mathrm{kg}^{-1}$ (Deviana, 2014). Hal ini menyebabkan lahan yang digunakan memiliki kandungan unsur hara yang cukup memadai sehingga dapat menunjang pertumbuhan tanaman jagung manis. Sarief (1986) menyatakan bahwa dengan tersedianya unsur hara dalam jumlah yang cukup pada saat pertumbuhan vegetatif, maka proses fotosintesis akan berjalan aktif, sehingga proses pembelahan, pemanjangan, dan diferensiasi sel akan berjalan lancar. Sehingga pada kontrol (tanpa perlakuan) pertumbuhan tinggi dan jumlah daun tanaman tidak berbeda nyata dengan perlakuan dengan pupuk.

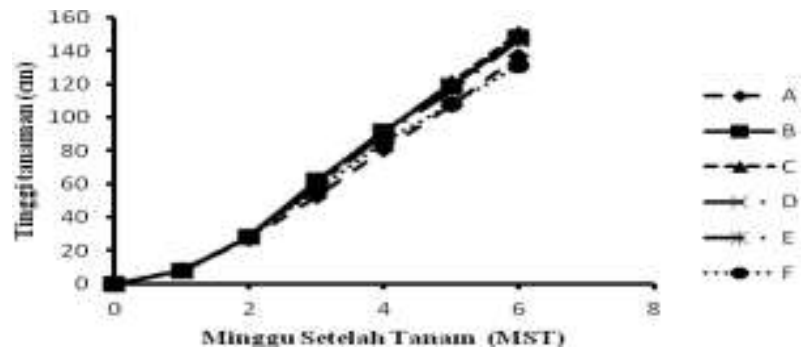

Keterangan: Angka-angka yang diikuti huruf yang sama pada setiap kolom tidak berbeda nyata berdasarkan uji BNT pada

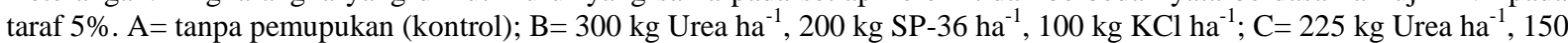
kg SP-36 ha ${ }^{-1}, 75 \mathrm{~kg} \mathrm{KCl} \mathrm{ha}^{-1}, 1000 \mathrm{~kg}$ Organonitrofos ha ${ }^{-1} ; \mathrm{D}=150 \mathrm{~kg}_{\text {Urea ha }}{ }^{-1}, 100 \mathrm{~kg} \mathrm{SP}-36 \mathrm{ha}^{-1}, 50 \mathrm{~kg} \mathrm{KCl} \mathrm{ha}^{-1}, 1.500$ $\mathrm{kg}$ Organonitrofos ha ${ }^{-1} ; \mathrm{E}=75 \mathrm{~kg} \mathrm{Urea} \mathrm{ha}^{-1}, 50 \mathrm{~kg} \mathrm{SP}-36 \mathrm{ha}^{-1}, 25 \mathrm{~kg} \mathrm{KCl} \mathrm{ha}^{-1}, 2.000 \mathrm{~kg}^{-}$Organonitrofos ha ${ }^{-1} ; \mathrm{F}=3.000 \mathrm{~kg}$ Organonitrofos ha ${ }^{-1}$.

Gambar 1. Pengaruh aplikasi pupuk Organonitrofos dan kombinasinya dengan pupuk kimia terhadap tinggi tanaman jagung pada fase vegetatif akhir pada musim tanam ke tiga $(\mathrm{cm})$.

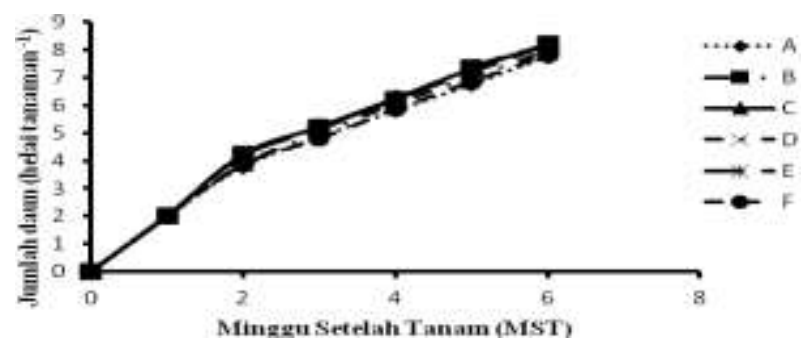

Keterangan: Angka-angka yang diikuti huruf yang sama pada setiap kolom tidak berbeda nyata berdasarkan uji BNT pada

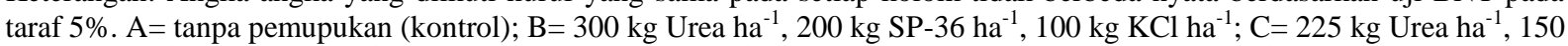
kg SP-36 ha ${ }^{-1}, 75 \mathrm{~kg} \mathrm{KCl} \mathrm{ha}^{-1}, 1000 \mathrm{~kg}$ Organonitrofos ha ${ }^{-1} ; \mathrm{D}=150 \mathrm{~kg} \mathrm{Urea} \mathrm{ha}^{-1}, 100 \mathrm{~kg} \mathrm{SP}-36 \mathrm{ha}^{-1}, 50 \mathrm{~kg} \mathrm{KCl} \mathrm{ha}^{-1}, 1.500$

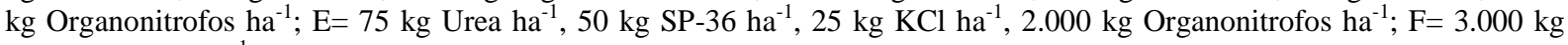
Organonitrofos $\mathrm{ha}^{-1}$.

Gambar 2. Pengaruh aplikasi pupuk Organonitrofos dan kombinasinya dengan pupuk kimia terhadap jumlah daun tanaman jagung pada fase vegetatif akhir pada musim tanam ke tiga (helai $\left.\operatorname{tanaman}^{-1}\right)$. 
Pengaruh Aplikasi Pupuk Organonitrofos dan Kombinasinya dengan Pupuk Kimia terhadap Pertumbuhan Generatif Tanaman Jagung Manis

Pengaruh pemberian pupuk tidak berbeda nyata terhadap pertumbuhan generatif tanaman jagung dengan parameter yang digunakan yaitu bobot basah tongkol dengan kelobot bobot basah tongkol tanpa kelobot dan bobot basah berangkasan. Namun, berdasarkan perhitungan data perlakuan D

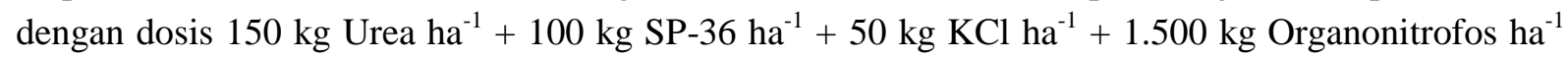
menunjukkan bobot basah tongkol dengan kelobot, bobot basah tongkol tanpa kelobot, dan bobot basah berangkasan tertinggi (Gambar 3, 4 dan 5).

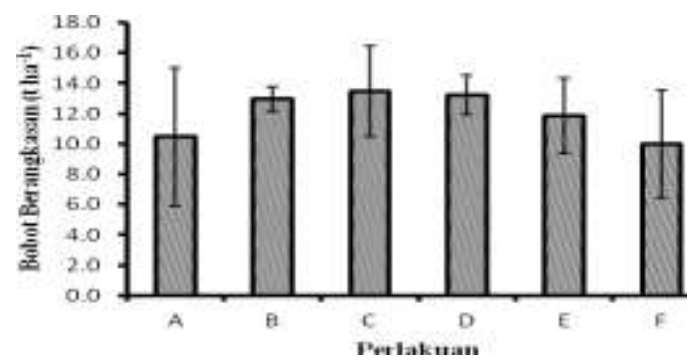

Keterangan: Angka-angka yang diikuti huruf yang sama pada setiap kolom tidak berbeda nyata berdasarkan uji BNT pada

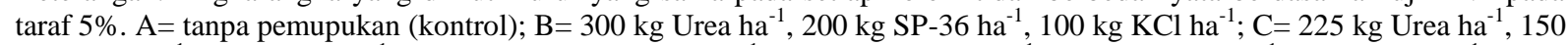
kg SP-36 ha ${ }^{-1}, 75 \mathrm{~kg} \mathrm{KCl} \mathrm{ha}^{-1}, 1000 \mathrm{~kg}$ Organonitrofos ha ${ }^{-1}$; D= $150 \mathrm{~kg}$ Urea ha ${ }^{-1}, 100 \mathrm{~kg} \mathrm{SP}-36 \mathrm{ha}^{-1}, 50 \mathrm{~kg} \mathrm{KCl} \mathrm{ha}^{-1}, 1.500$ $\mathrm{kg}$ Organonitrofos ha $\mathrm{h}^{-1} ; \mathrm{E}=75 \mathrm{~kg} \mathrm{Urea} \mathrm{ha}^{-1}, 50 \mathrm{~kg} \mathrm{SP}-36 \mathrm{ha}^{-1}, 25 \mathrm{~kg} \mathrm{KCl} \mathrm{ha}^{-1}, 2.000 \mathrm{~kg}$ Organonitrofos ha ${ }^{-1} ; \mathrm{F}=3.000 \mathrm{~kg}$ Organonitrofos ha ${ }^{-1}$.

Gambar 3. Pengaruh aplikasi pupuk Organonitrofos dan kombinasinya dengan pupuk kimia terhadap bobot basah berangkasan pada musim tanam ke tiga $\left(\right.$ t.ha $\left.{ }^{-1}\right)$.

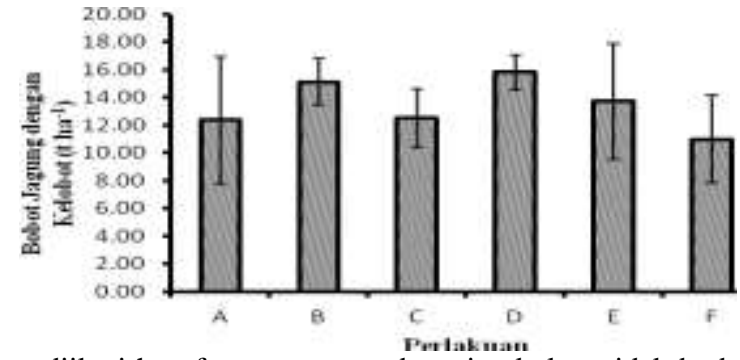

Keterangan: Angka-angka yang diikuti huruf yang sama pada setiap kolom tidak berbeda nyata berdasarkan uji BNT pada taraf 5\%. A=tanpa pemupukan (kontrol); B= $300 \mathrm{~kg} \mathrm{Urea} \mathrm{ha}^{-1}, 200 \mathrm{~kg} \mathrm{SP}^{-36 \mathrm{ha}^{-1}, 100 \mathrm{~kg} \mathrm{KCl} \mathrm{ha}}{ }^{-1} ; \mathrm{C}=225 \mathrm{~kg} \mathrm{Urea} \mathrm{ha}^{-1}, 150$ kg SP-36 ha ${ }^{-1}, 75 \mathrm{~kg} \mathrm{KCl} \mathrm{ha}^{-1}, 1000 \mathrm{~kg}$ Organonitrofos ha $^{-1}$; D= $150 \mathrm{~kg} \mathrm{Urea} \mathrm{ha}^{-1}, 100 \mathrm{~kg} \mathrm{SP}-36 \mathrm{ha}^{-1}, 50 \mathrm{~kg} \mathrm{KCl} \mathrm{ha}^{-1}, 1.500$ $\mathrm{kg}$ Organonitrofos ha ${ }^{-1} ; \mathrm{E}=75 \mathrm{~kg} \mathrm{Urea} \mathrm{ha}^{-1}, 50 \mathrm{~kg} \mathrm{SP}-36 \mathrm{ha}^{-1}, 25 \mathrm{~kg} \mathrm{KCl} \mathrm{ha}^{-1}, 2.000 \mathrm{~kg}$ Organonitrofos ha $^{-1} ; \mathrm{F}=3.000 \mathrm{~kg}$ Organonitrofos ha ${ }^{-1}$.

Gambar 4. Pengaruh aplikasi pupuk Organonitrofos dan kombinasinya dengan pupuk kimia terhadap bobot basah tongkol dengan kelobot pada musim tanam ke tiga $\left(\right.$ t.ha $\left.^{-1}\right)$.

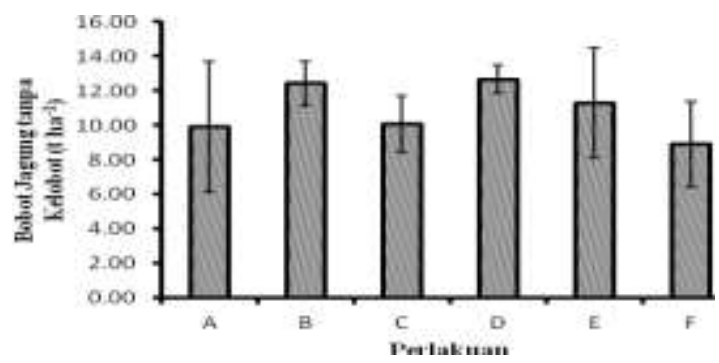

Keterangan: Angka-angka yang diikuti huruf yang sama pada setiap kolom tidak berbeda nyata berdasarkan uji BNT pada taraf 5\%. A = tanpa pemupukan (kontrol); B= $300 \mathrm{~kg} \mathrm{Urea} \mathrm{ha}^{-1}, 200 \mathrm{~kg} \mathrm{SP}^{-36 \mathrm{ha}^{-1}, 100 \mathrm{~kg} \mathrm{KCl} \mathrm{ha}}{ }^{-1} ; \mathrm{C}=225 \mathrm{~kg} \mathrm{Urea} \mathrm{ha}^{-1}, 150$ kg SP-36 ha ${ }^{-1}, 75 \mathrm{~kg} \mathrm{KCl} \mathrm{ha}^{-1}, 1000 \mathrm{~kg}$ Organonitrofos ha $^{-1}$; D= $150 \mathrm{~kg}$ Urea ha $^{-1}, 100 \mathrm{~kg} \mathrm{SP}-36 \mathrm{ha}^{-1}, 50 \mathrm{~kg} \mathrm{KCl} \mathrm{ha}{ }^{-1}, 1.500$ $\mathrm{kg}$ Organonitrofos ha $\mathrm{h}^{-1} ; \mathrm{E}=75 \mathrm{~kg} \mathrm{Urea} \mathrm{ha}^{-1}, 50 \mathrm{~kg} \mathrm{SP}-36 \mathrm{ha}^{-1}, 25 \mathrm{~kg} \mathrm{KCl} \mathrm{ha}^{-1}, 2.000 \mathrm{~kg}$ Organonitrofos ha ${ }^{-1} ; \mathrm{F}=3.000 \mathrm{~kg}$ Organonitrofos $\mathrm{ha}^{-1}$.

Gambar 5. Pengaruh aplikasi pupuk Organonitrofos dan kombinasinya dengan pupuk kimia terhadap bobot basah tongkol tanpa kelobot pada musim tanam ke tiga $\left(\mathrm{t} \mathrm{ha}^{-1}\right)$. 
Eka Purnama Sari dkk: Uji Efektivitas Pupuk Organonitrofos dan Kombinasinya dengan Pupuk Kimia...

Pengaruh Aplikasi Pupuk Organonitrofos dan Kombinasinya dengan Pupuk Kimia terhadap Serapan Hara Total Tanaman Jagung Manis

Hasil penelitian menunjukkan bahwa serapan N, P, K tanaman jagung manis berbeda nyata. Dari hasil penelitian menunjukkan bahwa serapan hara N-total tertinggi terdapat pada perlakuan $\mathrm{D}$ sebesar 91,12 $\mathrm{kg} \mathrm{ha}^{-1}$, diikuti oleh perlakuan B (100\% NPK) sebesar 86,73 $\mathrm{kg} \mathrm{ha}^{-1}$ yang tidak berbeda nyata dengan perlakuan kombinasi $\mathrm{C}$ dan $\mathrm{E}$ (Tabel 2). Hal ini menunjukkan bahwa pemberian pupuk Organonitrofos mampu memberikan nutrisi yang cukup terhadap tanaman. Akan tetapi Serapan hara $\mathrm{N}$ tanaman jagung manis mengalami penurunan. Hal ini disebabkan oleh kandungan $\mathrm{N}$ didalam tanah juga rendah. Menurut (Soepardi, 1983), nitrogen jumlahnya di dalam tanah sedikit, sedangkan yang diserap tanaman tiap tahunnya sangat banyak. Hal lain yang menyebabkan rendahnya $\mathrm{N}$ adalah sifat unsur hara $\mathrm{N}$ yang mudah tercuci dan menguap.

Tabel 2. Pengaruh aplikasi pupuk Organonitrofos dan kombinasinya dengan pupuk kimia terhadap serapan hara $\mathrm{N}, \mathrm{P}$, dan $\mathrm{K}$ total tanaman jagung manis pada musim tanam ke tiga.

\begin{tabular}{cccc}
\hline Perlakuan & Serapan N $\left(\mathrm{kg} \mathrm{ha}^{-1}\right)$ & Serapan P $\left(\mathrm{kg} \mathrm{ha}^{-1}\right)$ & Serapan K $\left(\mathrm{kg} \mathrm{ha}^{-1}\right)$ \\
\hline A & $46,46 \mathrm{a}$ & $3,48 \mathrm{a}$ & $22,53 \mathrm{a}$ \\
B & $86,73 \mathrm{~b}$ & $6,82 \mathrm{~b}$ & $49,9 \mathrm{~cd}$ \\
C & $72,91 \mathrm{ab}$ & $4,32 \mathrm{a}$ & $42,3 \mathrm{bcd}$ \\
D & $91,12 \mathrm{~b}$ & $7,61 \mathrm{~b}$ & $54,36 \mathrm{~d}$ \\
E & $66,85 \mathrm{ab}$ & $4,03 \mathrm{a}$ & $39,96 \mathrm{bc}$ \\
F & $53,27 \mathrm{a}$ & $3,28 \mathrm{a}$ & $29,18 \mathrm{a}$ \\
\hline BNT 0,05 & 27,17 & 2,11 & 14,30 \\
\hline
\end{tabular}

Keterangan: Angka-angka yang diikuti huruf yang sama pada setiap kolom tidak berbeda nyata berdasarkan uji BNT pada taraf 5\%. A = tanpa pemupukan (kontrol); B= $300 \mathrm{~kg} \mathrm{Urea} \mathrm{ha}^{-1}, 200 \mathrm{~kg} \mathrm{SP}^{-36 \mathrm{ha}^{-1}, 100 \mathrm{~kg} \mathrm{KCl} \mathrm{ha}}{ }^{-1} ; \mathrm{C}=225 \mathrm{~kg} \mathrm{Urea} \mathrm{ha}^{-1}, 150$ kg SP-36 ha ${ }^{-1}, 75 \mathrm{~kg} \mathrm{KCl} \mathrm{ha}^{-1}, 1000 \mathrm{~kg}$ Organonitrofos ha ${ }^{-1}$; D=150 kg Urea ha ${ }^{-1}, 100 \mathrm{~kg} \mathrm{SP}-36 \mathrm{ha}^{-1}, 50 \mathrm{~kg} \mathrm{KCl} \mathrm{ha}^{-1}, 1.500$ $\mathrm{kg}$ Organonitrofos ha ${ }^{-1}$; E $=75 \mathrm{~kg} \mathrm{Urea} \mathrm{ha}^{-1}, 50 \mathrm{~kg} \mathrm{SP}-36 \mathrm{ha}^{-1}, 25 \mathrm{~kg} \mathrm{KCl} \mathrm{ha}{ }^{-1}, 2.000 \mathrm{~kg}$ Organonitrofos ha ${ }^{-1} ; \mathrm{F}=3.000 \mathrm{~kg}$ Organonitrofos $\mathrm{ha}^{-1}$.

Unsur hara $\mathrm{P}$ yang diserap oleh tanaman bergantung pada ketersediaan $\mathrm{P}$ dalam tanah. Serapan P-total tertinggi sebesar 7,61 kg ha ${ }^{-1}$ juga terdapat pada perlakuan D dengan dosis $150 \mathrm{~kg}$ urea ha ${ }^{-1}, 100 \mathrm{~kg} \mathrm{SP}-36 \mathrm{ha}^{-1}, 50 \mathrm{~kg} \mathrm{KCl} \mathrm{ha}{ }^{-1}, 1500 \mathrm{~kg}$ Organonitrofos $\mathrm{ha}^{-1}$ namun tidak berbeda nyata terhadap perlakuan B dengan dosis pupuk $300 \mathrm{~kg} \mathrm{ha}^{-1}$ urea, $200 \mathrm{~kg} \mathrm{ha}^{-1} \mathrm{SP}-36,100 \mathrm{~kg} \mathrm{ha}^{-1} \mathrm{KCl}$ (Tabel 2). Hal ini menunjukkan bahwa perlakuan $D$ mampu meningkatkan ketersediaan $P$ dalam larutan tanah sehingga mampu meningkatkan serapan $\mathrm{P}$ oleh tanaman. Adapun pada perlakuan kombinasi yang digunakan sumber hara $\mathrm{P}$ berasal dari pupuk Organonitrofos (berasal dari batuan fosfat dan kotoran sapi) yang mengandung hara $\mathrm{P}$ yang cukup memadai yaitu 3,4\% dan juga pupuk SP-36. Menurut Noor (2005), meningkatnya serapan $\mathrm{P}$ tanaman baik pada pemberian fosfat alam maupun bakteri pelarut fosfat dan pupuk kandang, disebabkan karena meningkatknya kandungan P-tersedia di dalam tanah.

Serapan hara K-total tertinggi juga terdapat pada perlakuan D (150 kg urea ha ${ }^{-1}, 100 \mathrm{~kg} \mathrm{SP}-36$ $\mathrm{ha}^{-1}, 50 \mathrm{~kg} \mathrm{KCl} \mathrm{ha}^{-1}, 1500 \mathrm{~kg}$ Organonitrofos ha ${ }^{-1}$ ) sebesar 54,36 $\mathrm{kg} \mathrm{ha}^{-1}$ diikuti oleh perlakuan B yaitu sebesar 49,9 $\mathrm{kg} \mathrm{ha}^{-1}$ yang tidak berbeda nyata dengan perlakuan kombinasi $\mathrm{C}$ dan $\mathrm{E}$ (Tabel 2). Hal ini menunjukkan bahwa perlakuan D mampu meningkatkan ketersediaan $\mathrm{K}$ dalam larutan tanah sehingga mampu meningkatkan serapan K oleh tanaman. Menurut Lumbantobing et al., (2008) pupuk organik yang mengandung mikroba mampu meningkatkan efisiensi penyerapan unsur hara oleh tanaman yang tercermin dari peningkatan pertumbuhan, produksi, dan serapan hara tanaman. 


\section{Hasil Uji Efektivitas Pupuk Organonitrofos}

Hasil perhitungan RAE menunjukan bahwa penggunaan pupuk Organonitrofos dan kombinasinya dengan pupuk kimia pada perlakuan $\mathrm{D}$ bersifat lebih baik dibandingkan dengan perlakuan A (kontrol), C, dan E, namun perlakuan F (3.000 kg Organonitrofos ha ${ }^{-1}$ ) hasil perhitungan RAE kurang baik jika dibandingkan dengan perlakuan lainnya. Berdasarkan analisis pupuk Organonitrofos secara agronomi terhadap biomass total jagung manis pada penelitian ini, perlakuan D dengan dosis $150 \mathrm{~kg}$ Urea ha- ${ }^{-1}, 100 \mathrm{~kg} \mathrm{SP}-36 \mathrm{ha}^{-1}, 50 \mathrm{~kg} \mathrm{KCl} \mathrm{ha}{ }^{-1}, 1.500 \mathrm{~kg}$ Organonitrofos ha- ${ }^{-1}$ menghasilkan efektivitas sebesar 108,573\%. RAE perlakuan D tersebut 104,5\% persen lebih besar dibandingkan dengan penggunaan pupuk kimia standar pada perlakuan B dengan dosis $300 \mathrm{~kg}$ Urea $\mathrm{ha}^{-1}, 200 \mathrm{~kg} \mathrm{SP}-36 \mathrm{ha}^{-1}, 100 \mathrm{~kg} \mathrm{KCl} \mathrm{ha}{ }^{-1}$. Sedangkan dosis tunggal pupuk Organonitrofos (F) hanya menghasilkan nilai RAE sebesar -25,659\% (Tabel 3).

Tabel 3. Hasil perhitungan Relative Agronomic Effectiviness (RAE) pada biomass total tanaman jagung manis di musim tanam ke tiga.

\begin{tabular}{ccc}
\hline Perlakuan & Biomass Total Jagung Manis $\left(\mathrm{t} \mathrm{ha}^{-1}\right)$ & RAE Biomass Total $(\%)$ \\
\hline A & 5,751 & - \\
B & 7,234 & 100 \\
C & 6,384 & 42,686 \\
D & 7,361 & 108,573 \\
E & 6,323 & 38,609 \\
F & 5,371 & $-25,659$ \\
\hline
\end{tabular}

Keterangan: $\quad$ Bila nilai $\mathrm{RAE} \geq 100 \%$ maka pupuk yang diuji bersifat efektif dibanding perlakuan pupuk standar (B). $\mathrm{A}=$ tanpa pemupukan (kontrol); $\mathrm{B}=300 \mathrm{~kg} \mathrm{Urea} \mathrm{ha}^{-1}, 200 \mathrm{~kg} \mathrm{SP}-36 \mathrm{ha}^{-1}, 100 \mathrm{~kg} \mathrm{KCl} \mathrm{ha}^{-1} ; \mathrm{C}=225 \mathrm{~kg} \mathrm{Urea} \mathrm{ha}^{-1}, 150 \mathrm{~kg} \mathrm{SP}-36$ $\mathrm{ha}^{-1}, 75 \mathrm{~kg} \mathrm{KCl} \mathrm{ha}^{-1}, 1000 \mathrm{~kg}$ Organonitrofos ha ${ }^{-1} ; \mathrm{D}=150 \mathrm{~kg} \mathrm{Urea} \mathrm{ha}{ }^{-1}, 100 \mathrm{~kg} \mathrm{SP}-36 \mathrm{ha}^{-1}, 50 \mathrm{~kg} \mathrm{KCl} \mathrm{ha}{ }^{-1}, 1.500 \mathrm{~kg}$ Organonitrofos ha ${ }^{-1}$; E $=75 \mathrm{~kg}$ Urea ha ${ }^{-1}, 50 \mathrm{~kg} \mathrm{SP}^{-36 \mathrm{ha}^{-1}, 25 \mathrm{~kg} \mathrm{KCl} \mathrm{ha}{ }^{-1}, 2.000 \mathrm{~kg} \text { Organonitrofos ha }}{ }^{-1} ; \mathrm{F}=3.000 \mathrm{~kg}$ Organonitrofos $\mathrm{ha}^{-1}$.

\section{Hasil Uji Ekonomis Pupuk Organonitrofos}

Berdasarkan hasil uji ekonomis yang dilakukan secara ekonomis perlakuan B (300 kg Urea ha ${ }^{-1}$, $200 \mathrm{~kg} \mathrm{SP}-36 \mathrm{ha}^{-1}, 100 \mathrm{~kg} \mathrm{KCl} \mathrm{ha}^{-1}$ ) adalah yang paling menguntungkan. Terlihat pada Tabel 4 nilai ratio yang diperoleh dengan menggunakan pupuk subsidi sebesar 29,37, sedangkan pada perhitungan pupuk non-subsidi (eceran) didapatkan nilai ratio 8,16 dan 14,30 untuk nilai ratio pupuk non-subsidi (partai besar). Dengan demikian apabila dilakukan usaha budidaya jagung manis, maka dosis pada perlakuan B lebih menguntungkan secara ekonomi.

Tabel 4. Hasil perhitungan uji ekonomis pupuk Organonitrofos berdasarkan perbandingan antara penerimaan total dengan biaya total pada musim tanam ke tiga.

\begin{tabular}{cccc}
\hline \multirow{2}{*}{ Perlakuan } & \multicolumn{3}{c}{ Ratio } \\
\cline { 2 - 4 } & Subsidi & Non-subsidi (eceran) & Non-subsidi(partai besar) \\
\hline A & 0 & 0 & 0 \\
B & 29,37 & 8,16 & 14,30 \\
C & 13,83 & 6,67 & 9,64 \\
D & 10,32 & 6,38 & 8,25 \\
E & 9,44 & 7,42 & 8,50 \\
F & 6,36 & 6,36 & 6,36 \\
\hline
\end{tabular}

Keterangan: Jika nilai yang dihasilkan $>1$, maka pupuk yang diuji memiliki nilai ekonomis yang baik. $\mathrm{A}=$ tanpa pemupukan

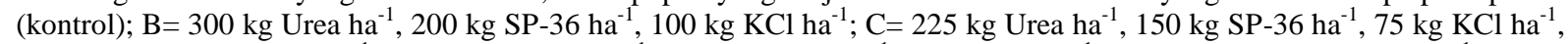

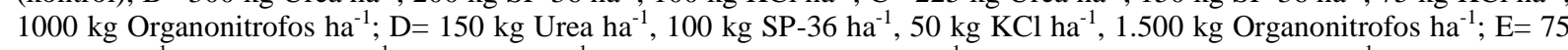
$\mathrm{kg} \mathrm{Urea} \mathrm{ha}{ }^{-1}, 50 \mathrm{~kg} \mathrm{SP}-36 \mathrm{ha}^{-1}, 25 \mathrm{~kg} \mathrm{KCl} \mathrm{ha}^{-1}, 2.000 \mathrm{~kg}$ Organonitrofos ha $^{-1} ; \mathrm{F}=3.000 \mathrm{~kg}$ Organonitrofos ha ${ }^{-1}$. 


\section{KESIMPULAN}

(1) Pemberian pupuk Organonitrofos dan kombinasinya dengan pupuk kimia dengan dosis 150 $\mathrm{kg}$ Urea ha ${ }^{-1}+100 \mathrm{~kg} \mathrm{SP}-36 \mathrm{ha}^{-1}+50 \mathrm{~kg} \mathrm{KCl} \mathrm{ha}^{-1}+1.500 \mathrm{~kg}$ organonitrofos ha ${ }^{-1}$ (Perlakuan D) mampu meningkatkan serapan hara $\mathrm{N}, \mathrm{P}$, dan $\mathrm{K}$ total pada tanaman jagung manis, namun belum mampu meningkatkan pertumbuhan dan produksi tanaman jagung manis, (2) Pemberian pupuk Organonitrofos dan kombinasinya dengan pupuk kimia dengan dosis $150 \mathrm{~kg}$ Urea ha $^{-1}+100 \mathrm{~kg}$ SP-36 $\mathrm{ha}^{-1}+50 \mathrm{~kg} \mathrm{KCl} \mathrm{ha}^{-1}+1.500 \mathrm{~kg}$ organonitrofos ha ${ }^{-1}$ (Perlakuan D) secara RAE memberikan pengaruh terbaik terhadap biomass total tanaman jagung manis, (3) Pemberian pupuk kimia secara ekonomis dengan dosis $300 \mathrm{~kg}$ Urea ha $^{-1}, 200 \mathrm{~kg} \mathrm{SP}-36 \mathrm{ha}^{-1}, 100 \mathrm{~kg} \mathrm{KCl} \mathrm{ha}^{-1}$ (Perlakuan B) bersifat paling menguntungkan apabila dilakukan usaha budidaya jagung manis.

\section{DAFTAR PUSTAKA}

Agromedia. 2010. Kondisi Kelangkaan Pupuk Subsidi di Pasaran. [Diakses pada 20 September 2013] http://www.agromedia.go.id. Indonesia.

Badan Koordinasi Penanaman Modal. 2011. Potensi investasi provinsi lampung 2011 (http://regionalinvestment.bkpm.go.id/newsipid/id/userfiles/ppi/Potensi\%20Investasi\%20Provi nsi\%20Lampung\%202011.PDF). Diakses pada 10 Juli 2014. $20 \mathrm{hlm}$.

Deviana, M. 2014. Pengaruh Pemberian Pupuk Organonitrofos Dan Kombinasinya Dengan Pupuk Kimia Terhadap Serapan Hara Dan Produksi Tanaman Jagung (Zea Mays L.) di Musim Tanam Ke Dua Pada Tanah Ultisol Gedung Meneng. Skripsi. Universitas Lampung. 75 hlm.

Direktorat Jenderal Hortikultura. 2012. Volume impor dan ekspor sayuran tahun 2012 (http://hortikultura.deptan.go.id/). Diakses pada 15 Agustus 2014.

Koswara, J. 1986. Budidaya Jagung Manis (Zea mays saccharata). Bahan Kursus Budidaya Jagung Manis dan Jamur Merang. Fakultas Pertanian IPB Bogor. 75 hlm.

Lumbantobing, E. L. N., F. Hazra, dan I. Anas. 2008. Uji Efektivitas Bio-Organic Fertilizer (Pupuk Organik Hayati) dalam Mensubstitusi Kebutuhan Pupuk Anorganik pada Tanaman Sweet Sorghum [Sorghum bicolor (L.) Moench]. Jurnal Tanah Lingkungan. 10(2): 72-76.

Noor, A. 2003. Pengaruh Fosfat Alam dan Kombinasi Bakteri Pelarut Fosfat dan Pupuk Kandang terhadap P Tersedia dan Pertumbuhan Kedelai pada Ultisol. Buletin Agronomi 31(3): 100-106.

Nugroho, S. G., Dermiyati, J. Lumbanraja, S. Triyono, H. Ismono, Y. T. Sari, dan E. Ayuandari. 2012. Optimum Ratio of Fresh Manure and Grain Size of Phosphate Rock Mixture in a Formulated Compost for Organomineral NP Fertilizer. Jurnal Tanah Tropika 17 (2): 121-128.

Prahastuti, S. W. 2005. Perubahan Beberapa Sifat Kimia dan Serapan P Jagung Akibat Pemberian Bahan Organik dan Batuan Fosfat Alam pada Ultisol Jasinga. Jurnal Agroland 12:(1) ; 68-74

Rosmarkam, A dan N. W Yuwono. 2002. Ilmu Kesuburan Tanah. Kanisius. Yogyakarta.

Rukmana, R. 1997. Jagung. Kanisius. Yogyakarta. 84 hlm.

Sarief, E. S. 1986. Kesuburan dan Pemupukan Tanah Pertanian. Pustaka Buana. Bandung. 182 hlm. 
Septima, A. R. 2012. Uji Efektivitas Pupuk Organonitrofos dan Kombinasinya dengan Pupuk Kimia Terhadap Pertumbuhan, Produksi Tanaman Jagung. Skripsi. Universitas Lampung. Bandar Lampung. $80 \mathrm{hlm}$.

Soepardi, G. 1983. Sifat dan Ciri Tanah. Fakultas Pertanian. Institut Pertanian Bogor. Bogor. 591 hlm.

Sutejo, M. M. 1995. Pupuk dan Cara Pemupukan. Rineka Cipta, Jakarta. 177 hlm.

Syukur, A. 2005. Penyerapan Posfor oleh Tanaman Jagung di Tanah Pasir Pantai Bugel dalam Kaitannya dengan Tingkat Frekuensi Penyiraman dan Pemberian Bahan Organik. Jurnal Ilmu Tanah dan Lingkungan Vol 5, No.2 : 20-26. 